adhesion to surrounding tissues is found, resort may have to be had to the method of Krönlein. Birch-Hirschfeld expressed the opinion that unless the growth is removed complete, the malignancy is increased and, for this reason, the Krönlein method of exposure, offering as it does freer access, is recommended by some authorities.

\title{
REFERENCES
}

Adami.-Principles of Pathology

Birch-Hirschfeld.-Arch. f. Ophthal., 1915.

Bruner.-Amer. Jl. of Ophthal., Vol. VII, pp. 755-758, 1924.

Collins and Mayou.-Pathology and Bacteriology of the Eye. 2nd Edition. 1925.

Crawley.-Trans. Ophthal. Soc. U.K., Vol. XLIV, pp. 425-

Ewing - Neoplastic Diseases. 1928.

Greeves.-Roy. Lond. Ophthal. Hosp. Repts., pp. 237-263, 1914.

Habermann.-Inaug. Dis., Jena, 1918.

Klemptner.-Northwest Med., Vol. XXVI, pp. 212-213, 1927.

Lagrange.-Traité de Tumeurs de l'oeil, etc. p. 610. Paris, 1914.

Lane.-Amer. Jl. of Ophthal., Vol. V, pp. 425-434, 1922 (Bibliography.)

Parsons.-Pathology of the Eye. Vol. II, pp. 752-757 (Bibliography).

Pfingst.-Trans. Amer. Ophthal. Soc., Vol. XXIII, pp. 33-50.

Sgrosso.-Arch. di Ottal., Vol. I, pp 121-128, 1893.

van Duyse and Weymeersch.-Bull. Soc. belge d'ophtal., No. 56, pp. 28-33, 1928.

Verhoeff.-Ji. Med. Res., 1904.

Warthin.-Arch. of Ophthal., 1901.

Wood.-Ann. of Surg., 1904.

\section{A RAPIDLY-GROWING MALIGNANT TUMOUR OF THE LACRYMAL GLAND}

BY

\author{
Dr. G. H. Pearson \\ WESLEYAN MISSION hOSPITAL, PAOKING, HUNAN, CHINA
}

Patient, a Chinese, Li Shen-Chuin, a farmer, aged 21 years. Case No. 16216. Seen at Wesleyan Mission Hospital, Paoking, Hunan, China, April $7,1930$.

Clinical History._." Patient came to hospital on April 2, 1930, for treatment for his eye which was covered by a projecting tumour. This tumour, he states definitely, has only grown during the last 40 days, previous to which he had nothing the matter at all. For the past 20 days it has been getting red and inflamed and for 12 days he has noticed the gland in front of his ear which is painful.

"Present Condition: The patient is a healthy well-nourished farmer boy. Temperature and pulse normal. No sign of any disease beyond his eye trouble. Skin particularly clean and healthy. There is a large swelling of the whole of the upper lid of the right eye, which stands out almost at right angles to the face. The 
projecting conjunctiva along the lower edge of the upper lid is thick and swollen and shows a tendency to bleed readily if touched. The whole lid feels oedematous or pulpy, but just below the upper margin of the orbit the skin is easily movable and a soft tumourmass, almost fluctuating, can be palpated. The fluctuation, however, is not definite and exploration for pus with a hypodermic needle yields a trace of blood.

"The bulbar conjunctiva is oedematous, but the lower lid seems unaffected. The eye itself is in its normal position, there being no exophthalmos. If the swollen lid is held back by a retractor, the cornea is seen to be normal and vision is also normal.

"Glands: The preauricular glands on the affected side are markedly swollen and tender. The swelling is diffuse and illdefined, extending into the parotid region. There is no discoloration, redness or fluctuation.

“April 15, 1930.-Operation.-A preliminary diagnosis was made of malignant growth of the lacrymal gland. As it seemed possible to remove the growth and to have enough tissue left to reconstruct the eyelid, operation was decided upon. On the day previous to operation it was noticed that enlargement of the lower lid was beginning.

"A preliminary incision was first made vertically into the substance of the upper lid, in order to define the condition of the tissue there. It was at once evident that no operation other than complete evisceration of the orbit plus parotid gland, etc., would be of any use. As permission could not be obtained for this, a small section was removed for examination and the skin sutured. The conjunctiva was so friable that no suture would hold in it. The whole of the swelling in the lid was found to consist of a soft grey rapidly-growing tumour, which lay right up against the skin of the eyelid and was actually involving the conjunctiva and intimately attached to it. What had appeared to be oedema was actually part of the growth itself. The growth also extended now quite half way round the margin of the lower lid."

Pathological Report:-A section of the tissue removed was carefully preserved in Müller's fluid and sent to the Department of Ophthalmology at Peiping (Peking) where a section was prepared and reported on as follows :-

“May 6, 1930.-Microscopic Examination: Sections show a strip of skin tissue, underneath which there are compact masses of cells suggesting a malignant tumour. On account of the poor fixation of the tissue submitted, it is not possible to make any definite diagnosis, the details of the cells being very much blurred due to shrinkage and other destructive changes. A large number of eosinophiles are seen immediately beneath the epidermis.

"Impression: A malignant tumour of eye (type?).

$$
\text { Dr. L. Sallmann/W. P. Ling." }
$$




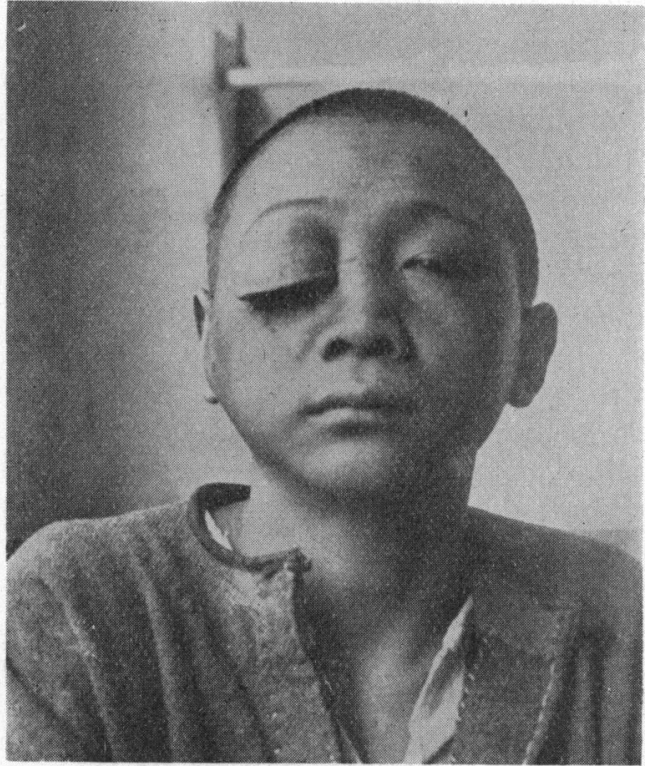

Fig. 1.

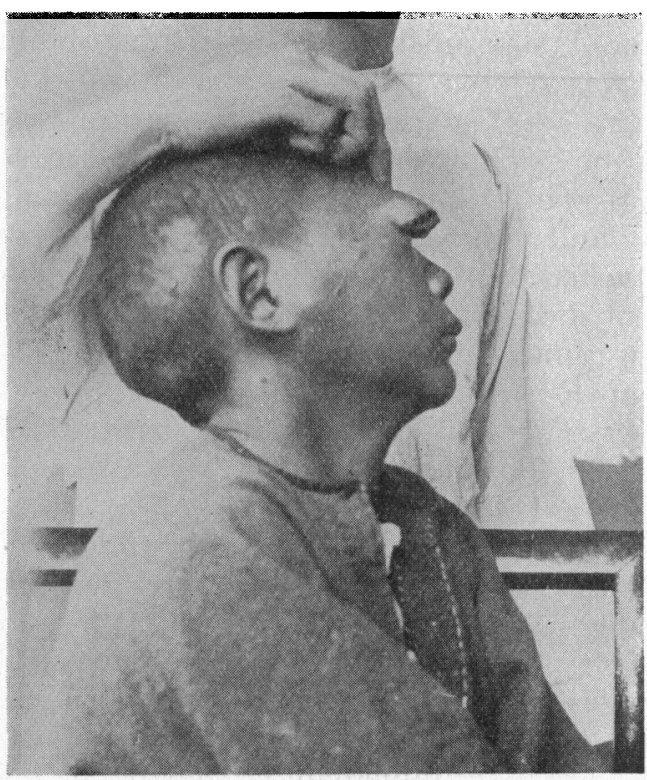

FIG. 2. 
I later submitted the specimen to Dr. R. Howard Mole, Pathologist to Birkenhead and Wirral Children's Hospital; etc., who reports as follows :-

"With regard to section submitted, there is no doubt whatever of its malignancy, and I think the cells are epithelial, of what origin I cannot say. There is abundant evidence of cellular mitosis. There is also some lymphocyte and polymorphonuclear celled infiltration. The tumour is moderately vascular."

Thus, apparently, we would be justified in calling this a case of malignancy of the lacrymal gland, notable for its extremely rapid growth of only 40 days up to the inoperable stage shown in the accompanying two photographs.

\section{A NOTE ON GONIN'S OPERATION FOR DETACHED RETINA}

BY

J. HeRbert Fisher

LONDON

WHEN the inflammatory exudate from iritis organizes to form a membranous disc which blocks the pupil aperture the pupil of the eye is said to be " occluded." The obstructing membrane is never so dense as to prevent the filtration through it of aqueous fluid from the posterior to the anterior compartment of the chamber.

Iris bombé results from the formation of an annular posterior synechia, when the pupil is said to be "excluded ": in this condition the aqueous secretion, being excluded from the anterior compartment, is retained behind the iris, which becomes bellied forward.

In the light of recent knowledge our former incapacity to deal successfully with a detached retina in which a hole could be recognized appears to have been due to the fact that even if by operative or other measures the subretinal fluid could be drained off it was at once replaced by further fluid which flowed, through the hole, from the vitreous humour. The point essential to secure the very practical success which attends Gonin's operation is said to be the " sealing of the hole" in the retina. The determination of the exact point over the hole at which to puncture the sclerotic and choroid with the cautery is a pre-requisite of success. The term "sealing the hole" suggests that the cautery point is passed through the hole in the retina, sears its margins and thus stimulates the production from the retinal tissue of an inflammatory 